\title{
ARTIFICIAL RESPIRATION, THE HISTORY OF AN IDEA
}

by

\section{A. BARRINGTON BAKER}

Thou takest away their breath, they die, and return to their dust.

Psalms 104, 29.

\section{INTRODUCTION}

THE SIMPLE automatic act of breathing is essential to life, but may be interrupted in a variety of ways. Cessation of this act of breathing is not necessarily fatal if there is some means available to produce artificial respiration. However, should this assistance be lacking then death will always supervene. This article proposes to sketch the history of the various means of artificial respiration and to discuss the effects of its development upon the progress of physiology, medicine, surgery and resuscitation.

\section{PRE-PHYSIOLOGY}

The oldest references to artificial respiration are in Egyptian mythology where by one account Isis resurrected Osiris with the breath of life. ${ }^{1}$ Other early references occur in the Bible in Genesis, 2, 7 and Kings I, 17, 21, both of doubtful physiological significance. However another Biblical reference is strongly quoted as evidence of artificial respiration.

And he went up and lay upon the child, and put his mouth upon his mouth, and his eyes upon his eyes, and his hands upon his hands: and he stretched himself upon the child; and the flesh of the child waxed warm.

Then he returned, and walked in the house to and fro; and went up and stretched himself upon him: and the child sneezed seven times, and the child opened his eyes.

Kings II, 4, 34-35

This reference is the best of the three but again the exact meaning is doubtful. It does appear that this could be a description of mouth to mouth respiration, even though the reason for recovery may well have been rewarming of the patient.

Despite these references the medical and lay populace do not seem to have used

1 W. A. Jayne, The Healing Gods of Ancient Civilisations, New Haven, Yale University Press, 1925, p. 65.

However, this myth is particularly complex and on checking Jayne's references on this point I was not able to locate his interpretation of the myth. The following translations by Wallis Budge throw some light on the interpretation:

'She [Isis] made light with her feathers, she made air to come into being with her wings, and she uttered cries of lamentation at the bier of her brother. She stirred up from his state of inactivity him whose heart was still.' Hymn to Osiris 1500 B.C., The Gods of the Egyptians, London, Methuen, 1904, vol. 2, p. 150.

'to breathe the breath of Isis', Pyramid Text-Unas, The Gods of the Egyptians, vol. 2, p. 204.

'When Isis wished to revivify Osiris she gathered together his fiesh, and bound up his hands, and embraced him'. Pyramid Text-Pepi II 868, Osiris and the Egyptian Resurrection, London, Warner, 1909, vol. 1, p. 86. 


\section{Artificial Respiration, the History of an Idea}

any form of artificial respiration for the dying or recently dead. Not only did they not use it for resuscitation, the lack of its use hindered their physiological study of the thoracic cavity and its organs. Without artificial respiration thoracotomy inevitably led to the collapse of one or both lungs, which usually resulted in the death of the animal in a short time and always to very severe interference with the physiological mechanisms. Galen was well aware of this problem and wrote of it on several occasions in his Anatomical Procedures, ${ }^{2}$ most graphically

For with this perforation [pleural membrane] the whole process of respiration is destroyed, while if it be not perforated you cannot see within the thorax at all, except by excising a rib and leaving the pleura unharmed."

For this operation it is best to use a large pig, for then the membrane lining the ribs is strong."

This method is of course a very poor one for visualizing the thoracic contents, as the pleural membrane is opalescent when it is thick enough not to be torn during dissection off the rib cage. Galen also describes in detail his method for exposing the heart of an animal for examination of its action, without perforation of the pleural membrane. ${ }^{6}$ A related approach via median sternotomy is today made by cardiac surgeons so that the pleural cavities are not disturbed and post-operative complications reduced in incidence and degree. Galen was obviously a very capable surgeon to be able to dissect his living animals to display the heart directly, or the thoracic contents through the pleural membrane, as these animals were not anaesthetized and even if well restrained would be hyperventilating with pain and fear. He was also prepared to use his surgical skill in the case of the slave Maryllus whose lower sternum he resected for a perichrondral infection, to expose the pulsating heart to the world. ${ }^{6}$ This is an operation which is unlikely to be undertaken lightly today, and that the slave lived can only be justification for the highest praise.

Galen, himself a great experimentalist, must have been very close indeed to discovering the usefulness of artificial ventilation, because in one of his experiments he used bellows to inflate the lungs of a dead animal. ${ }^{7}$ It is but a very simple step to doing exactly the same in a recently dead animal from an open thorax to discover that it is revived albeit temporarily.

The next reference to artificial ventilation, once again of almost folk-tale origin, concerns also mouth-to-mouth artificial respiration. In 1472 Bagellardus issued this advice to midwives: 'If she find it [the newborn] warm, not black, she should blow into its mouth, if it has no respiration.'8 Marvellous advice only to be ruined by the succeeding phrase 'or into its anus!' So it may be assumed that Bagellardus did not recognize the real significance of his advice.

Galen on Anatomical Procedures A.D. 177, trans. by Charles Singer, London, Wellcome Historical Museum, 1956, pp. 195, 196, 206-7, 207.

Ibid., p. 195.

Ibid., p. 206.

Ibid., p. 190-92.

- Ibid., p. 192.

7 Galen (A.D. 175), De usu partium corporis humani, lib. VII cap. IV, trans. by M. T. May, New York, Cornell University Press, 1968, p. 339.

'You can clearly see this for yourself even after the animal is dead, if you blow air through the rough artery into the whole lung and then empty it out again by pressure.'

- P. Bagellardus, Libellus de egritudinibus infantium, Barval, 1472, p. 3 unnumbered 'si reperiret ipsu calidu no nigru debet inflare in os eius ipso no habete respiratione aut in anu eius.' 


\section{A. Barrington Baker}

\section{PHYSIOLOGY}

Almost a century later Vesalius was describing in a matter-of-fact way his technique for keeping an experimental animal alive to examine its thoracic contents.

But that life may in a manner of speaking be restored to the animal, an opening must be attempted in the trunk of the trachea, into which a tube of reed or cane should be put; you will then blow into this, so that the lung may rise again and the animal take in air. Indeed, with a slight breath in the case of this living animal the lung will swell to the full extent of the thoracic cavity, and the heart become strong and exhibit a wondrous variety of motions. So, with the lung inflated once and a second time, you examine the motion of the heart by sight and touch as much as you wish.'

and later,

With this observed, the lung should again be inflated, and with this device, than which I have learned nothing more pleasing to me in Anatomy, great knowledge of the differences in the beats should be acquired. For when the lung, long flaccid, has collapsed, the beat of heart and arteries appears wavy, creepy, twisting, but when the lung is inflated, it becomes strong again and swift and displays wondrous variations. ${ }^{10}$

and again,

And as I do this (the anatomical dissection) and take care that the lung is inflated at intervals, the motion of heart and arteries does not stop. ${ }^{11}$

As can be seen it is not clear from the above excerpts whether Vesalius was copying a technique or whether he had invented it. The suggestion 'than which I have learned nothing more pleasing to me in Anatomy (quo mihi gratius in Anatome nullum comperi)' seems to indicate that it was shown to Vesalius, however I have been unable to ascertain a source from which Vesalius might have obtained the technique. It is not mentioned by Mondino dei Luzzi, ${ }^{12}$ nor does it appear to be known to the great experimentalist Leonardo da Vinci who though not a physician had a powerful friend in Marco Antonio della Torre, Professor of Anatomy at Padua and Pavia. However Leonardo did repeat the Galen experiment and concluded that, 'To me it seems impossible that any air can penetrate into the heart through the trachea, because he who inflates it, does not expire any part of air from any part of this.' ${ }^{13}$ He also tried to ascertain the mechanism of speech.

The extension and restriction of the trachea together with its dilatation and attraction are the cause of the varying of the voice of the animals from high to deep and from deep to high; as to which 2nd action, the shortening of this trachea, not being sufficient at the rising of the voice, it dilates itself somewhat towards the upper part, which receives no degree of sound (and) comes to raise the voice of this remnant of the shortened pipe. But on this we shall make an experiment in anatomizing the animals, giving air into their lungs and pressing them, narrowing and dilating the 'fistola', the generator of their voice. 14

- A. Vesalius, De humani corporis fabrica, Lib. VII Cap. XIX-De vivorum sectione nonnulla Basle, Oporinus, 1543, p. 658 (should be 662 but error in first edition).

${ }^{10}$ Ibid., p. 658-9 (really 662-63).

11 Ibid., p. 658 (really 663).

12 Personal communication from Dr. G. Whitteridge.

Mondino dei Luzzi (Mundinus), Anothomia, Pavia, A. de Carchano, 1478.

${ }^{18}$ Leonardo da Vinci, Quaderni d'Anatomia, 1513, II fol. 1, recto or p. 2, eds. Vangensten O. C. L., Fonahn A. and Hopstock H., Christiania, J. Dybwad, 1912.

${ }^{14}$ Leonardo da Vinci (c. 1507-1509) Quaderni d'Anatomia, IV vol. 10, verso or p. 18, eds. Vangensten

O. C. L., Fonahn A. and Hopstock H., Christiania, J. Dybwad, 1914. The Leonardo dates from 


\section{Artificial Respiration, the History of an Idea}

Like Galen, Leonardo was close to the fundamental discovery of artificial respiration.

It would appear that if Vesalius did obtain his technique from anyone it would have been early in the sixteenth century. There is a suggestion by Fodéré15 (unsubstantiated) that Paracelsus in 1530 tried bellows 'with moderation and gentleness' on a dead subject without success. Pagel has stated that he does not know of this reference in Paracelsus's texts. ${ }^{16}$ However Vesalius may well have been the person who chanced upon the technique, as he knew Galenic texts intimately and may well have carried out Galen's inflation experiment on a recently dead animal with surprising results. ${ }^{17}$ If he did invent the technique himself, its description must surely be the most modest for such dramatic revival. He may perhaps have feared the wrath of the Church.

From this time onwards the Vesalian technique may be assumed to have remained well known in Padua. Colombo mentions it, ${ }^{18}$ giving greater detail on the tracheotomy procedure, and Harvey very casually mentions it in De motu locali animalium: ' $a$ cock's head off, the arteries being ligatured and artificial ventilation being given.' 19 No doubt the anatomy demonstrations regularly made use of this method to display the actions of thoracic organs. Harvey also mentions that he repeated the Galen experiment of testing for air passage to the heart. ${ }^{20}$

Another casual reference to artificial respiration occurs in Highmore's Corporis humani disquisitio anatomica in $1651 .{ }^{21}$ However only thirteen years later and fifty miles away in London Croune was demonstrating to the Royal Society his revival of strangled chickens. ${ }^{22}$ Hooke, who was present at this demonstration, later makes a great show of reviving an open chested dog.

In prosecution of some inquiries into the nature of respiration in several animals, a dog was dissected, and by means of a pair of bellows, and a certain pipe thrust into the wind-pipe of the $\mathrm{dog}$, the heart continued beating for a very long while after all the thorax and belly had been opened; nay, after the diaphragm had been in great part cut away, and the pericardium removed from the heart. And from several trials made, it seemed very probable, that this motion might have been continued as long, almost, as there was any blood left within the vessels of the dog: for the motion of the heart seemed very little changed, after above an hour's time, from the first displaying the thorax; though we found, that upon removing the bellows, the lungs would presently grow flaccid, and the heart begin to have convulsive motions: but upon renewing the motion of the bellows, the heart recovered its former motion, and the convulsions ceased. ${ }^{23}$

K. Clark, The Drawings of Leonardo da Vinci in the Collection of Her Majesty the Queen at Windsor Castle, 2nd ed., London, Phaidon, 1968, vol. 3, p. 30 and 45.

${ }^{16}$ F. E. Fodéré, Dictionnaire des Sciences médicales, 1819, 34413.

Also W. Harrison, Detroit med. J., 1916, 16, 270. 'A brief historical review of the employment of a bellows as a means of inducing artificial respiration during the three hundred years which elapsed between A.D. 1530 and 1830.' Harrison most probably obtained his reference from Fodére though he gives no references.

16 W. Pagel, personal communication.

17 A. von Haller, Elementa physiologiae corporis humani, Tome III Respiratio-Vox, Lausanne, F. Grasset, 1766, p. 247 credits Vesalius with being the first to carry out 'Hooke's Experiment.'2s

${ }_{18}$ R. Colombo, De re anatomica, Lib. XIII, De viva sectione. p. 261, Venice, N. Beuilacquae, 1559.

$10 \mathrm{~W}$. Harvey, De motu locali animalium, 1627 (trans. G. Whitteridge, Cambridge, 1968, p. 1035).

$20 \mathrm{~W}$. Harvey, Exercitatio anatomica de motu cordis et sanguinis in animalibus, 1620 (trans. $R$. Willis, London, Sydenham Society, 1847, p. 16).

${ }_{21}$ N. Highmore, Corporis humani disquisitio anatomica, Lib. II, Pars III, Cap. III De usu \& motu pulmonum. Hague, Comitis S. Broun, 1651, p. 189-90.

${ }_{22} \mathrm{~W}$. Croune (1664), in T. Birch The History of the Royal Society of London for Improving of Natural Knowledge, London, A. Millar, 1756, vol. 1, p. 433.

s R. Hooke (1664), T. Birch, op. cit., vol. 1, p. 486. 


\section{A. Barrington Baker}

Then on 10 October $1667^{24}$ Hooke first performed his experiment, which was later reported in the Philosophical Transactions ${ }^{25}$ from the demonstration on 24 October, ${ }^{26}$ of keeping a dog alive without any respiratory movements by passing a constant flow of air into the animal. This experiment was very important as it convincingly proved that the heart's movements and those of respiration were independent, which had not previously been generally believed. ${ }^{27}$ At the end of this communication Hooke showed that he had a very good grasp of the possibility of extra-corporeal respiration, 'I shall shortly further try, whether the suffering the Blood to circulate through a vessel, so as it may be openly exposed to the fresh Air, will not suffice for the life of an animal.'25 However he lived before the isolation of oxygen and methods for providing a thin uncoagulated blood film, and his attempts were unsuccessful. Two hundred years more were to elapse before further experimentation was attempted, and 250 before success with this particular branch of artificial respiration.

Richard Lower, who was Hooke's associate in the dog experiment of 10 October but not credited in the Philosophical Transactions, also used artificial respiration on a dog to prove that the blood changed colour in the lungs and that this was dependent upon respiration or at least the passage of fresh air into the lungs. ${ }^{28}$ This evidence finally settled the change of colour of the blood in the lungs whereas previously it had been generally believed to be in the left heart, though this was at times debated.

Thus it can be seen that even after artificial respiration had been well described by

24 'The experiment of opening the thorax of a dog was made by Dr. Lower and Mr. Hooke, which succeeded well, as it had done formerly, according to the account already registered of it. ${ }^{23}$ Sir George Ent reflecting upon this experiment, said, that it shewed what was not the use of respiration, but not what it was: that the lungs not beating at all, but only kept extended with fresh air blown in by bellows, shewed, that the lungs did not serve to promote by their agitation the motion of the blood. Mr. Hooke considered, that the dog being continually supplied with fresh air was kept alive, but was ready to die, if either he was left unsupplied, or his lungs only kept full with the same air; and thence conceived, that the true use of respiration was to discharge the fumes of the blood.' $T$. Birch, op. cit., vol. II, p. 198.

is R. Hooke, Phil. Trans. R. Soc. Lond., 1667, 2, 539. An account of an experiment made by Mr. Hook, of preserving animals alive by blowing through their lungs with bellows.

The origin of this idea for artificial respiration which suddenly appeared to burst forth amongst the Royal Society is unreported. However Ralph Bathurst in his doctoral thesis (Praelectiones tres de respiratione. 1654. Printed in The Life and Literary Remains of Ralph Bathurst, by Thomas Wharton. London, R. \& J. Dodsley, 1761, p. 127.) shows that he had read critically Highmore's book ${ }^{21}$ and thus would know of the technique. Also he was friendly with Harvey when the latter was at Oxford, and the subject may well have been mentioned between them. The connexion may have been through Bathurst's membership of the Royal Society, but perhaps more likely through his intimacy with Thomas Willis who had Richard Lower as his apprentice. However the technique should have been known to the educated well-read physicians of the time. An interesting aside is that Borelli who compiled his great work during this era mentions only the experiments of Croune ${ }^{22}$ and has no mention of Vesalius or his followers (G. A. Borelli, De motu animalium, Rome, A. Bernabo, 1681, Pars Altera, p. 216).

T. Birch, op. cit., vol. II, p. 201.

"7 'Towards the latter end of this Experiment a piece of the Lungs was cut quite off; where 'twas observable, that the Blood did freely circulate, and pass thorow the lungs, not only when the Lungs were kept thus constantly extended, but also when they were suffer'd to subside and lye still. Which seem to be Arguments, that as the bare Motion of the Lungs without fresh Air contributes nothing to the life of the Animal, he being found to survive as well, when they were not mov'd, as when they were; so it was not the subsiding or movelesness of the Lungs, that was the immediate cause of Death, or the stopping the Circulation of the Blood through the Lungs, but the want of a sufficient supply of fresh Air.' Phil. Trans. R. Soc. Lond., 1667, $2,539$.

: R. Lower, Tractatus de corde, item de motu \& calore sanguinis et chyli in eum transitu, Cap. III Sanguinis motus \& calor p. 177/8, Amsterdam, D. Elzevirium, 1669. 


\section{Artificial Respiration, the History of an Idea}

Vesalius a further 120 years passed before the major physiology of the thorax had been determined. It was indeed a great restriction to the development of physiology that Galen did not chance upon the technique of artificial respiration.

\section{RESUSCITATION}

The idea of artificial ventilation may safely be said to have arrived with this age of great experimentation coinciding with the foundation of the Royal Society. Physiology seems never to have forgotten the technique again. However in the associated fields of medicine, surgery and resuscitation many years had to pass before acceptance of the idea.

During the eighteenth century, drowning became a major public and medical issue, and in the latter half of the century several societies were founded to promote the recovery of persons apparently drowned. ${ }^{29}$

\section{(a) Intermittent Positive Pressure Ventilation}

However, well before these, in 1740, the Académie des Sciences (Paris) had issued its 'Avis' which advised strongly that mouth-to-mouth respiration was the best method for recovering apparently drowned persons. ${ }^{30}$

The first authentic case of human recovery by artificial respiration would seem to be the report by Tossach in 1744 concerning the resuscitation of a suffocated miner using the mouth-to-mouth technique. 'I must submit to better Judges to determine whether the Experiment I design to relate was the Mean of saving the Man's Life on whom it was tried; it is at least very simple, and absolutely safe, and therefore can at least be no Harm, if there is not an Advantage in acquanting the Publick of it.' ${ }^{31}$ Tossach was a cautious as well as a clever innovator. Jackson ${ }^{32}$ also gives a very accurate description of mouth-to-mouth resuscitation, though not from personal experience. It was not long before the effectiveness of bellows was substituted as the motive force. Buchan clearly describes such recommended measures:

To renew the breathing a strong person may blow his own breath into the patient's mouth with all the force he can, holding his nostrils at the same time. When it can be perceived by the rising of the chest or belly that the lungs are filled with air, the persons ought to desist from blowing, and should press the breast and belly so as to expel the air again; and this operation may be repeated for some time, alternately inflating and depressing the lungs so as to imitate natural respiration. If the lungs cannot be inflated in this manner, it may be attempted by blowing through one of the nostrils and at the same time keeping the other close. Dr. Monro for this purpose recommends a wooden pipe fitted at one end for filling the nostril, and at the other end for being blown into by a person's mouth, or for receiving the pipe of a pair of bellows, to be employed for the same purpose, if necessary. When air cannot be forced into the chest by the mouth or nose, it may be necessary to make an opening in to the wind-pipe for this purpose."3

This is almost a modern resuscitation manual. However it was not long before

20 Amsterdam 1767; Milan and Hamburg 1768; Paris 1771; London 1774. The general social awareness of the times has been elegantly described by J. D. Herholdt and C. G. Rafn. An Attempt at an Historical Survey of Life-Saving Measures for Drowning Persons and information of the best means by which they can again be brought back to life, Copenhagen, H. Tikiøb, 1796 (trans. 1960 by D. W. Hannah and A. Rousing, ed. by H. Poulsen. Aarhuus, Stiftsbogtrykkerie.)

20 Réaumur, Avis concerant les personnes noyées, qui paraissent mortes, 1740, quoted in full by Louis, Lettres sur la certitude des signes de la mort, où l'on rassure les Citoyens de la crainte d'être enterrés vivans, avec des observations \& des expériences sur les noyés, Paris, Lambert, 1753, p. 250.

"1 W. Tossach, Medical Essays and Observations, Edinburgh, 1744, 5 (2), 605. 'A' man, dead in appearance recovered by distending the lungs with air.'

2 $\mathrm{R}$. Jackson, A Practical Dissertation on Drowning by a Physician (attributed to Jackson), London, J. Robinson, 1746, p. 68.

as W. Buchan, Domestic Medicine, London, W. Strahan, 1769, p. 672-3 (8th ed., 1784). 


\section{A. Barrington Baker}

Fothergill, probably the greatest worker of this resuscitation era, was pointing out the advantages of mouth-to-mouth over bellows,

(1) as the bellows may not be at hand;

(2) as the lungs of one man may bear, without injury, as great a force as those of another can exert, which by the bellows cannot always be determined;

(3) the warmth and moisture of the breath would be more likely to promote the circulation than the chilling air forced out of a pair of bellows.".

However with the discovery by Black in 1754 of carbon dioxide ${ }^{35}$ and of oxygen by Priestley, ${ }^{36}$ Lavoisier $^{37}$ and Scheele, ${ }^{38}$ mouth-to-mouth respiration was outmoded ${ }^{39}$ by positive pressure ventilation, firstly with bellows then with pistons. ${ }^{40}$ These pistons in some cases included a withdrawal phase as well to assist expiration-a technique used in modern times to assist venous return to the heart rather than expiration but a technique also with some attendant dangers..$^{90} \mathrm{John}$ Hunter in his writing on this subject showed his great practical ability with two suggestions: 'Perhaps the dephlogisticated air, described by Dr. Priestley may prove more efficacious than common air. It is easily procured, and may be preserved in bottles or bladders.' 11 and 'If during

" J. Fothergill, Phil. Trans. R. Soc. Lond., 1745, 43, 275. 'Observations on a case published in the last volume of the Medical Essays Etc. of recovering a man dead in appearance, by distending the lungs with air.'

${ }^{26} \mathrm{~J}$. Black, Dissertatio medica inauguralis de humore acido a cibis orto, et magnesia alba, Edinburgh, G. Hamilton \& J. Balfour, 1754.

so J. Priestley, Phil. Trans. R. Soc. Lond., 1772, 62, 147: 'Observations on different kinds of air.'

27 A. L. Lavoisier, Observations sur la Physique, sur l'Histoire Naturelle et sur les Arts, 1775, 5, 429: 'Mémoire sur la nature du principe qui se combine avec les métaux pendant leur calcination, \& qui en augmente le poids.'

${ }^{3}$ C. W. Scheele, Chemische Abhandlung von der Luft und dem Feuer, Uppsala and Leipzig, 1777, translated Alembic Club Reprint 8, Edinburgh, W. F. Clay, 1894.)

80 'the excellent experiments of Priestley and Fontana have demonstrated that the air leaving the chest contains a large quantity of phlogisticated air $\left(\mathrm{N}_{2}\right)$ and fixed air $\left(\mathrm{CO}_{2}\right)$, neither of which is of any use for respiration and far from aiding this function the fixed air which is found in the expiration, carries into the lungs a lethal effect.' $F$. Chaussier see note 40.

1 F. Chaussier, of Dijon (1780-81 but published Paris 1785) Histoire de la Société Royale de Médecine, 4, 346, 'Reflexions sur les moyens propres à déterminer la respiration dans les enfants qui naissent sans donner aucun signe de vie, \& a rétablir cette fonction dans les asphyxiés; \& sur les effets de l'air vital ou déphlogistiqué employé pour produire ces avantages.'

E. Coleman, A Dissertation on Suspended Respiration from Drowning, Hanging and Suffocation in which is recommended a different Mode of Treatment to any hitherto pointed out, London, J. Johnson, 1791.

L. H. Courtois, J. Méd. Chir. Pharm., 1790, 82, 361, 'Mémoire sur les asphyxiés, avec la description d'un nouvel instrument propre à rappeler le mechanisme de la respiration.'

J. Curry, Observations on Apparent Death from Drowning . . . etc., and an account of the means to be employed for recovery, 2nd ed., London E. Cox, 1815.

Desgranges, J. Méd. Chir. Pharm., 1791, 87, 288; 'Mémoire sur les moyens de perfectionner l'établissement public formé à Lyon en faveur des personnes noyées, avec des remarques sur la cause de leur mort, et le traitment qui leur convient.'

E. Goodwyn, The Connexion of Life with Respiration, London, J. Johnson, 1788.

Gorcy, J. Méd. Chir. Pharm., 1789, 79, 349, 'Mémoire sur les différens moyens de rapeller à la vie les asphyxiques.'

C. Kite, An Essay on the Recovery of the Apparently Dead, London, C. Dilly, 1788.

C. Kite, Mem. med. Soc. Lond., 1792, 3, 215; 'On the submersion of animals; its effects on the vital organs; and the most probable method of removing them.'

J. J. C. Legallois, Expériences sur le Principe de la Vie, Paris, D'Hautel, 1812.

C. C. H. Marc, Nouvelles Recherches sur les Secours a Donner aux Noyés et Asphyxiés, Paris, Crochard, 1835.

J. Murray, Lond. J. Arts Sci., 1822, 3, 93; 'Account of an apparatus for restoring the lost action of the lungs, in consequence of suspended animation from drowning etc.'

Rouland, Observations sur la Physique, sur l'Histoire Naturelle et sur les Arts . . ., 1790, 36, 118; 'Description d'un instrument au moyen duquel on peut rétablir la respiration.'

¿1 J. Hunter, Phil. Trans. R. Soc. Lond., 1776, 66, 412; 'Proposals for the recovery of people apparently drowned.' 


\section{Artificial Respiration, the History of an Idea}

this operation the larynx be gently pressed against the oesophagus and spine, it will prevent the stomach and intestines being too much distended by the air. ${ }^{41}$ This latter manoeuvre is in modern anaesthesia known as Sellick's manoeuvre after its modern proposer, ${ }^{42}$ some 200 years after Hunter's suggestion. Also this comment hints at one of the difficulties of the technique. It was not long before endotracheal intubation was being used for access to the lungs. Tracheotomy also was advised in some cases ${ }^{43}$ and occasionally bronchotomy, ${ }^{44}$ but because of their poor reputation in other conditions they lapsed in preference to endotracheal intubation, which was performed by blind techniques or by touch during this period. Tracheotomy presented the additional difficulty of air leak; a difficulty overcome in the endotracheal technique by wedging the tube in the larynx. The advent of cuffed tubes to seal the trachea did not occur for another hundred years. ${ }^{45}$

Early in the nineteenth century, doubts were raised concerning the safety of positive pressure respiration notably by Brodie, ${ }^{46}$ Villermé, ${ }^{47}$ and Vicq d'Azyr. ${ }^{48}$ The proof was delivered by Leroy in $1828^{49}$ when he reported the results of his experiments on animals which had been drowned, and recovery attempted by artificial respiration with bellows. The resultant emphysema was blamed on the bellows and it was not until 1888 that Paltauf ${ }^{50}$ demonstrated pulmonary emphysema to be a resultant of drowning per se, and Champneys ${ }^{51}$ that the lungs of dead infants withstood 20-80 $\mathrm{mm}$. Hg. pressure before rupturing. Even so in this century there were still complaints of the dangers. ${ }^{52}$ There was obvious division of opinion on these matters because,

12 B. A. Sellick, Lancet, 1961, ii, 404; 'Cricoid pressure to control regurgitation of stomach contents during induction of anaesthesia.'

Others who have also described this technique:

P. Scheel, Ueber Beschaffenheit und Nutzen des Fruchtwassers in der Luftröhre der menschlichen Früchte, Erlangen, 1800, p. 53. J. D. Herholdt, Commentation über das Leben, vorzüglich der Frucht im Menschen, und über den Tod unter der Geburt, Copenhagen, 1803, p. 164. R. Olshausen, Dtsch Klin., 1864, 16, 346, 357, 365. Die Behandlung scheintodter Neugeborener durch künstliche Respiration. Report of the Committee appointed by the Royal Medical and Chirurgical Society to investigate the subject of suspended animation, Med.-Chir. Trans., 1862, 45, 490.

is G. Detharding, 'De methodo subveniendi submersis per laryngotomiam,' 1714, quoted in A. von Haller, Disputationes Chirurgicae Selectae, Lausanne, Bousquet, 1755, Tome II, p. 427.

"1 E. Coleman, Trans. roy. hum. Soc., 1774-84, 1, 542, 'On the operation of bronchotomy.'

45 H. Head, J. Physiol., 1889, 10, 1 \& 279, 'On the regulation of respiration.'

V. Eisenmenger, Wien. med. Wosch., 1893, 43, 199, 'Zur Tamponade des Larynx nach Prof. Maydl.'

${ }^{16}$ B. Brodie, The Works of Sir Benjamin Collins Brodie, London, Longman, Green, Longman, Roberts \& Green, 1865, vol. 1, p. 420, 'Effects of strangulation.' Text published for the first time of a lecture given in 1821 to the Royal College of Surgeons, London.

${ }^{47}$ L. R. Villermé, Encyclopédie méthodique de la Médecine, Paris, 1824, Tome 11, p. 6, Noyés (pathologie), Traitement.

48 Vicq D'Azyr (1789)-report on memoir sent to the Société Royale de Médecine 28.7.1789 Supplement aux memoires sur les noyés p. 31. Quoted by Fodéré, note 15. (I have been unable to locate this reference in the original.)

'0 J. Leroy, J. Physiol. exp. Path., (Magendie), 1827, 7, 45, 'Recherches sur l'asphyxie.'

J. Leroy, J. Physiol. exp. path. (Magendie), 1828, 8, 97, 'Second mémoire sur l'asphyxie.'

${ }^{\text {so }}$ A. Paltauf, Über den Tod durch Ertrinken, Vienna and Leipzig, Urban \& Schwarzenberg, 1888.

s1 F. H. Champneys, Experimental Researches in Artificial Respiration in Stillborn Children, and Allied Subjects, London, Lewis, 1887, p. 122, chap. VI, 'Expiratory cervical emphysema, that is, emphysema of the neck occurring during labour and during violent expiratory efforts.'

${ }_{63}$ S. Jellinek, Wien. Med. Woch., 1931, 81, 1643, 'Gefahren der künstlichen Atmung. Eine experimentelle Studie.'

Y. Henderson, J. Amer. med. Ass., 1937, 109, 1561, 'Resuscitation.'

Y. Henderson, Science, 1943, 98, 547, 'The return of the Pulmotor as a "Resuscitator": a back-step toward the death of thousands.' 


\section{A. Barrington Baker}

although the Royal Humane Society abandoned bellows and positive pressure resuscitation in their official resuscitation scheme, the Edinburgh Almanack for 1834 quotes,

v. In order to restore breathing, introduce the pipe of a common bellows (where the apparatus of the Society is not at hand) into one nostril, carefully closing the other one and the mouth; at the same time drawing downwards and pushing gently backwards the upper part of the windpipe, to allow a more free admission of air; blow the bellows gently, in order to inflate the lungs, till the breast be a little raised; the mouth and nostrils should then be set free, and a moderate pressure made with the hand upon the chest. Repeat this process till life appears. ${ }^{\mathrm{bs}}$

\section{(b) Tank Respirators}

Also about this time Dalziel ${ }^{54}$ had invented the first tank respirator which operated by causing a subatmospheric pressure to be exerted on the outside of the thorax thus allowing the more positive pressure of the atmosphere to cause respiration. This particular technique for artificial respiration did not become popular, though Lewins wrote enthusiastically of it..$^{55}$ As the effects on the lungs are little different from normal positive pressure ventilation it is likely that it suffered with bellows, pistons and mouth-to-mouth as a result of Leroy's article and the appraisal of the article by Magendie and Duméril. ${ }^{56}$ This criticism of positive pressure techniques was one of the reasons for the enthusiasm which greeted the manual techniques discussed below. The tank respirator was reintroduced again by Hauke, ${ }^{57}$ and also by Woillez. ${ }^{58}$

\section{Zur Notiz!}

At the session of the Ac. de Med. of 20th June 1876 (Gaz. des Hop. 72) M. Woillez read a paper on an apparatus called 'Spirophore' resuscitating asphyxiated persons. Concerning the structure and method of application, this apparatus by Wolliez is however nothing else but a copy of my 'Pneumatic Tub'. Woillez does not give any hint to the fact that I first suggested this method and carried out experiments with it. Two years ago I published an article on the 'Pneumatic Cuirass' in which I described the first experiments with ill children; the inventor of the 'Spirophore' is quite silent about this.".0

In 1880 Waldenburg introduced the first cuirass respirator. ${ }^{60}$ This is a respirator working on the same principle as the tank respirators but covering only the thorax and not enclosing the body as the tank respirators do. Doe in 1889 described Braun's tank respirator for newborn babies. ${ }^{61}$ Following this spate of activity interest

63 The Edinburgh Almanack or Universal Scots and Imperial Register, Oliver \& Boyd, Edinburgh, 1834, p. 407.

s J. Dalziel, British Association for the Advancement of Science, Report for 1838, 2, 127, 'On sleep, and an apparatus for promoting artificial respiration.'

${ }_{b 5}$ 'I have nothing further to add at present, but the reiteration of the opinion expressed above, viz. that this invention is one fraught with importance to humanity and medical science.' Lewins, Edinburgh med. surg. J., 1840, 54, 255, 'Apparatus for promoting respiration in cases of suspended animation.'

s6 F. Magendie and A. M. C. Duméril, J. Physiol. exp. path. (Magendie), 1829, 9, 97, 'Rapport fait à l'Académie des Sciences sur un mémoire de M. Leroy D'Etoilles, relatif à l'insufflation du poumon, considérée comme moyens de secours à donner aux personnes noyées ou asphyxiées.'

${ }_{67}$ I. von Hauke, Wien. Med. Presse, 1874, 15, 785, 836, 'Der pneumatische Panzer. Beitrag zur "mechanischen Behandlung der Brustkrankheiten":

so Woillez, Bull. Acad. Méd, 1876, 2nd Ser., 5, 611, 'Du spirophore, appareil de sauvetage pour le traitement de l'asphyxie, et principalement de l'asphyxie des noyés et des nouveaunés.'

${ }^{\circ} \mathrm{I}$. von Hauke, Neue Pneumatische Apparate und ihre anwendung in der Kinderpraxis, Vienna, W. Braumüller, 1876, p. 21.

${ }^{60} \mathrm{~L}$. Waldenburg, Die Pneumatische Behandlung der Respirations und Circulationskrankheiten im Anschluss an die Pneumatometrie und Spirometrie, Berlin, Hirschwald, 1880.

'1 O. W. Doe, Boston med. surg. J., 1889, 120, 9: 'Apparatus for resuscitating asphyxiated children.' 


\section{Artificial Respiration, the History of an Idea}

disappeared in this form of treatment until Stewart and Rogoff ${ }^{62}$ in 1918 and later Drinker and McKhann ${ }^{63}$ produced their versions for use in the treatment of anterior poliomyelitis. Modifications flourished over the next ten years and a Medical Research Council Report deals fully with the various types produced. ${ }^{64}$ At this time just before the Second World War Lord Nuffield issued his offer to send one of these models (the Both) ${ }^{65}$ anywhere in the British Commonwealth.

Whilst on this subject, mention must be made of Thunberg's 'Barospirator's6 used in the treatment of poliomyelitis by Petrén and Sjövall. ${ }^{67}$ Also about this time, in 1938, a blistering article ${ }^{68}$ appeared in the Bulletin de l'Académie de Médecine claiming Woillez as the originator of the tank respirator. As has been pointed out, this author is incorrect by forty years. Tank respirators, although successful in terms of ventilating the patient, proved very unwieldy for nursing procedures and rapidly lost favour when better alternatives became available.

\section{(c) Manual Methods of Artificial Respiration}

To return to the first half of the nineteenth century, we continue the examination of the methods of resuscitation for the drowned, which still had great public emphasis. Leroy himself had suggested a many-tailed bandage which was alternately tightened and loosened. However there had been a manual method of artificial respiration described by De Haen in $1783^{69}$ and the Royal Humane Society in 1812 mentions manual methods. ${ }^{70}$ Dalrymple produced a different bandage from Leroy for the Royal Humane Society; ${ }^{71}$ suction cups were produced for attachment to the chest; $;^{72}$ and Van Hasselt described a method for lifting the rib cage by pushing fingers beneath the thoracic margin. ${ }^{73}$ However the greatest impetus to manual methods was given in 1855-56 by Marshall Hall. ${ }^{74}$ This new method was followed quickly by Silvester's, ${ }^{75}$ and for the remainder of the century fierce controversy raged as to the best method. This controversy has been well described by Karpovitch. ${ }^{76}$ There were numerous

"2 G. N. Stewart, and J. M. Rogoff, J. Lab. clin. Med., 1918, 4, 73: 'A contribution to the technic of artificial respiration in man.'

e. Drinker and C. F. McKhann, J. Amer. med. Assoc., 1929, 92, 1658: 'The use of a new apparatus for the prolonged administration of artificial respiration.'

P. Drinker, T. J. Shaughnessy and D. P. Murphy, J. Amer. med. Ass., 1930, 95, 1249: 'The Drinker respirator. Analysis of case reports of patients with respiratory failure treated from October 1928 to June 1930.'

* Medical Research Council, Special Report No. 237, 'Breathing Machines and their use in Treatment', London, H.M.S.O., 1939.

os The Times, 24 November 1938.

i T. Thunberg, Skand. Arch. Physiol., 1926, 48, 80: 'Der Barospirator, Ein neuer Apparat für künstliche Atmung.'

${ }^{\circ}$ K. Petrén and E. Sjövall, Acta med. Scand., 1926, 64, 260: 'Eine Studie über die tödliche akute Form der Poliomyelitis.'

'8 Woillez (d'Arras), Bull. Acad. Méd., 1938, 119, 82: 'Le spirophore, inventé en 1876.'

6o A. von Haen, Heilungsmethode, Leipzig, Weygand, 1783, 6, pp. 130-31, 134 and 7, pp. 304, 310.

70 Royal Humane Society, Annual Report, 1812, p. 9.

71 J. Dalrymple, Royal Humane Society Annual Report, 1833, pp. 24 and 99.

${ }^{72}$ H. Hans, Verhl. disch. Ges. inn. Med., 1934, 46, 228; 'Ein neues, sehr einfaches und doch sehr wirksames Verfahren zur künstlichen Beatmung.'

7 A. W. M. Van Hasselt, De Kunstmatige ademhaling tot herstelling van schijndooden, Utrecht, J. G. van Terveen, 1847, p. 60 .

74 M. Hall, Lancet, 1856, i, 144 Report only; 229 On a new mode of effecting artificial respiration; 393 Asphyxia its rationale and its remedy; ii, 5. Further note on apnoea and asphyxia.

Editorial Lancet, 1856, ii, 654.

76 H. R. Silvester, Lancet, 1858, i, 353, 616, The Marshall Hall method in the treatment of asphyxia.

70 P. V. Karpovitch, Adventures in Artificial Respiration, New York, Association Press, 1953. 


\section{A. Barrington Baker}

attempts to adjudicate between the methods, the most notable being by Djelitzin in $1893^{77}$ and the monumental inquiry in England headed by Schafer. ${ }^{78}$ This latter inquiry added yet another method to those available and found in favour of this latter method, later to be known as Schafer's method. Some of the experiments employed to test these various techniques were themselves rather heroic. In one ${ }^{79}$ a medical student volunteered to be deeply anaesthetized to apnoea-a very dangerous procedure at any time-then allowed the various methods of artificial respiration to be tried for their relative effectiveness! Schafer's method tended to hold sway until 1932 when Holger Nielsen described his method which then supplanted all previous manual methods. ${ }^{80}$ However not all opinions were in favour of manual methods as can be seen from Woods (1906),

but it seems to me to be clear from every consideration that the mouth-to-mouth or nose method gives the patient the best chance, for, to recapitulate:-

(1) The quantity of tidal air is greater than by any indirect method, and, therefore, the stimulation of the mechanisms of circulation and respiration, the elimination of the poison, and the oxygenation of the blood are all as great as possible.

(2) The impurities, if present at all, are neglible.

(3) The method can be applied without a moment's loss of time. ${ }^{81}$

This advice is today current. However, Woods was not to prevail just yet, and even as recently as 1951 a comprehensive investigation of methods of artificial respiration by the National Research Council gave its imprimatur to Holger Nielsen's method without even considering mouth-to-mouth respiration. ${ }^{82}$ Only since 1958 has mouthto-mouth respiration been returned to popularity as the method of choice in emergency resuscitation. ${ }^{83}$

\section{SURGERY}

However to return to the end of the nineteenth century, at this time experimental and therapeutic surgery of the thoracic cage and organs was being obstructed by the same problem which had frustrated the early physiologists. The chest could not be opened without the patient dying. 'Hundreds of thousands of people are succumbing

" S. N. Djelitzin, Khirurgitchesky Vestnck, 1893, 9, 484, Abstracted in: Centralblat. Chirg., 1893, 20, 841: 'Uber kunstliche Athmung.'

${ }_{78}$ E. A. Schafer, Med.-Chir. Trans., 1904, 87, 609: 'Description of a simple and efficient method of performing artificial respiration in the human subject especially in drowning to which is appended instructions for the treatment of the apparently drowned.'

E. A. Schafer, Proc. Roy. Soc. Edinb., 1904, 25 (pt. 1), 39: 'The relative efficiency of certain methods of performing artificial respiration in man.'

E. A. Schafer, Artificial Respiration in Man. The Harvey Lectures, Philadelphia, J. B. Lippincott, 1907-8, p. 223.

${ }^{79}$ A. Keith and L. Hill, Lond. Hosp. Gaz., 1908, 14, 206: 'The results of some enquiries into the Schäffer method of performing artificial respiration on the apparently drowned.'

${ }^{30}$ H. Nielsen, Ugeskz. f. Laeger, 1932, 94, 1201 : 'En oplivningsmetode.'

81 Woods, Trans. Roy. Acad. Med. Ir., 1906, 24, 136: 'On artificial respiration.'

82 National Research Council, Division of Medical Sciences. Minutes of meeting 1 October 1951, quoted by Karpovitch, note 76.

${ }_{83}$ P. Safar, L. A. Escarraga and J. O. Elam, New Engl. J. Med., 1958, 258, 671: 'A comparison of the mouth-to-mouth and mouth-to-airway methods of artificial respiration with the chest-pressure arm-lift methods.'

H. Poulsen, J. Skall-Jensen, I. Staffeldt and M. Lange, Acta Anaesth. Scand., 1959, 3, 129: 'Pulmonary ventilation and respiratory gas exchange during manual artificial respiration and expired air resuscitation on apnoeic normal adults.' 


\section{Artificial Respiration, the History of an Idea}

to tuberculosis, because as yet no one has been able to operate inside the thorax.'84

\section{(a) Intermittent Positive Pressure Ventilation}

The answer was not only centuries old, but also all around as it was in constant use' $^{85}$ in the physiological laboratory. Also it was being used in cases of poisoning by Fell, ${ }^{86}$ and it was in fact a modification of Fell's positive pressure technique which was advised by Parham, ${ }^{87}$ who incidently gives a very thorough table of all the previous successful intrathoracic operations on humans starting with Richerand in 1818. Tuffier and Hallion's technique ${ }^{88}$ (1906) was similar but used an expiratory resistance to keep the lung partially inflated for surgery upon it. This technique is the same as that used today with only minor modification.

All were not agreed upon the best method to use and Sauerbruch described a subatmospheric operating theatre inside which was everything except the patient's head. ${ }^{89} \mathrm{He}$ persisted with this technique for many years even when the positive pressure method had become generally established. With the acceptance of the positive pressure method there arose automatic mechanical devices to produce an intermittent flow. Some of the more important early models being those of Matas, ${ }^{90}$ Janeway, ${ }^{91}$ Dräger, ${ }^{92}$ Giertz, ${ }^{93}$ while the first truly automatic ventilator was described by Bowditch in 1879-80 for use in physiology:

The most perfect method of keeping an animal alive by artificial respiration is doubtless by means of bellows driven by a steam, gas or water motor. Where power of this sort is not to be had the object can be accomplished by breaking up the steady stream of air supplied by a waterbellows, or tromp, into a succession of impulses following each other at a rate corresponding to the normal respiratory movements of the animal."4

Parallel with this interest in positive pressure ventilation came the invention of direct laryngoscopy by Kirstein in $1895^{\circ 5}$ and the greater use of cuffed endotracheal p. 40 .

'T. Sauerbruch, A Surgeon's Life, trans. F. G. Renier and A. Cliff, London, A. Deutsch, 1953,

Bs. Matas, Ann. Surg., 1899, 29, 409: 'On the management of acute traumatic pneumothorax.'

s6 G. E. Fell, Buffalo med. surg. J., 1887, 28, 145: 'Forced respiration in opium poisoning-its possibilities, and the apparatus best adapted to produce it.'

67 F. W. Parham, Thoracic Resection for Tumours, New Orleans, Dornan, 1899, p. 130.

os Tuffier (and Hallion), Presse méd., 1906, 14, 57: 'L'Ouverture de la plère sans pneumothorax.'

'0 F. Sauerbruch, Mitt. grenzgeb. Med. Chir., 1904, 13, 399: 'Zur Pathologie des offenen Pneumothorax und die Grunlagen meines Verfahrens zu seiner Ausschaltung.'

${ }^{\infty} \mathrm{R}$. Matas, Am. Med., 1902, 3, 97: 'Artificial respiration by direct intralaryngeal intubation with a modified O'Dwyer tube and a new graduated air-pump, in its applications to medical and surgical practice.'

${ }^{\circ}$ N. W. Green, Surg. Gyn. Obstet., 1906, 2, 512: 'The positive-pressure method of artificial respiration with a practical device for its application in thoracic surgery, together with a report of transpleural operations in fourteen dogs.'

N. W. Green and H. H. Janeway, Ann. Surg., 1910, 52, 58: 'Artificial respiration and intrathoracic oesophageal surgery.'

H. H. Janeway, Ann. Surg., 1912, 56, 328: 'An apparatus for intratracheal insufflation.'

H. H. Janeway, Ann. Surg., 1913, 58, 927 : 'Intratracheal anaesthesia (A) by nitrous oxide and oxygen (B) By nitrous oxide and oxygen under conditions of differential pressure.'

¿Dräger Ltd., Pulmotor, 1911.

22 K. H. Giertz, Uppsala Läkaref. förh. Suppl., 1916-17, 22, 1; 'Studier öfver tryckdifferensandning enligt Sauerbruch och öfver konstgjord andning (rytmisk luftinble̊sning) vid intrathoracala operationer. Ommenperientella lungexstirpationer.'

K. H. Giertz, Dtsch Ztschr. Chir., 1914, 126, 167: 'Eine neue Modifikation der Sauerbruchschen Unterdruckkammer.'

ot H. P. Bowditch, J. Physiol. (Lond.), 1879-80, 2, 202: 'Physiological apparatus in use at the Harvard Medical School.'

${ }^{\circ 6}$ A. Kirstein, Berl. klin. Wosch., 1895, 32, 476: 'Autoskopie des larynx und der trachea'. 


\section{A. Barrington Baker}

tubes to prevent the leakage of gas. Thus the technique first described beautifully by Vesalius finally entered the everyday practice of surgery-an example of failure of communication that would have befitted the Dark Ages.

\section{(b) Apnoeic Respiration}

In the early years of this century the famous experiment of Hooke and Lower ${ }^{27}$ was re-studied in various physiological laboratories, apparently without knowledge of the prior effort nor of one another. Nagel ${ }^{96}$ in 1900 curarized pigeons and passed air retrogressively into the opened humerus (into which the lung extends) and this air eventually escaped via the trachea. This work was followed by others who all insufflated air into the tracheas of various animals. ${ }^{97,98}$ This latter method was later introduced as a technique for humans in 1951,99 and is currently used in anaesthesia for certain conditions. This technique cannot be relied upon for longterm artificial respiration because of the build-up of body carbon dioxide, ${ }^{97}$ and also requires oxygen as the delivery gas for any longer than a few minutes otherwise hypoxia cccurs. ${ }^{100}$

\section{(c) Extracorporeal Respiration}

Hooke's suggestion for extracorporeal respiration was revived by Legallois in $1812^{101}$ and later experimentally by Brown-Séquard and others ${ }^{102}$ in the latter part

06 W. A. Nagel, Centrlbl. Physiol., 1900, 14, 553: 'Uber künstliche Athmung mit continuirlichem Luftstrom bei Vögeln.'

${ }^{\circ 7}$ F. Volhard, Miunch. med. Wosch., 1908, 55 (1), 209: 'Ueber künstliche Atmung durch Ventilation der Trachea und eine einfache Vorrichtung zur rhytmischen künstlichen Atmung.'

'H H. Hirsch, Über künstliche Atmung durch Ventilation der Trachea, O. Kindt, Gissen, 1905. Barthélemy and Dufour, Presse méd., 1907, 15, 475: 'L'Anesthésie dans la chirurgie de la face.'

S. Robinson, J. Amer. med. Ass., 1908, 51, 803: 'Artificial intrapulmonary positive pressure. Experimental applications in surgery of the lungs.'

L. Brauer, Mitt. Grenzgeb. Med. Chir,. 1904, 13, 483: 'Die Ausschaltung der Pneumothoraxfolgen mit Hilfe des Ueberdruck-verfahrens.'

S. J. Meltzer and J. Auer, J. exper. Med., 1909, 11, 622: 'Continuous respiration without respiratory movements.'

S. J. Meltzer, J. Amer. med. Ass., 1911, 57, 521: 'Intratracheal insufflation.'

J. Auer and S. J. Meltzer, J. exper. Med., 1911, 14, 569: 'The status of respiration in the methods of differential pressure compared with that under the method of intratracheal insufflation.'

C. A. Elsberg, Med. Rec., 1910, 77, 494: "The value of continuous intratracheal insuffiation of air (Meltzer) in thoracic surgery; with description of an apparatus.'

'0 H. Enghoff, M. H. Holmdahl and P. L. Risholm, Nature (Lond.), 1951, 168, 830: 'Diffusion respiration in man.'

100 M. H. Holmdahl, Acta chir. Scand. Suppl., 1956, 212, 1 : 'Pulmonary uptake of oxygen, acid-base metabolism and circulation during prolonged apnoea.'

101 'If one could substitute for the heart a kind of injection of artificial blood, either naturally or artificially made, one would succeed in maintaining alive indefinitely any part of the body whatsoever.'

J. J. C. Legallois, Experiénces sur le Principe de la Vie, notamment sur celui des mouvements du coeur, et sur le siege de ce principe, Paris, D'Hautel, 1812, p. 134-5.

108 E. Brown-Séquard, J. Physiol. (Brown-Sequard), 1858, 1,95, 353, 729: 'Recherches expérimentales sur les propriétés physiologiques et les usages du sang rouge et du sang noir et de leurs principaux éléments gazeux, l'oxygène et l'acide carbonique.'

C. F. W. Ludwig, Die physiologischen Leistungen des Blutdrucks, Leipzig, S. Hirzel, 1865.

W. von Schröder. Naunyn-Schmiedeberg's Arch. exp. Path. Pharmak, 1882, 15, 364: 'Ueber die Bildungsstătte des Harnstoffs.'

M. von Frey and M. Gruber, Arch. Anat. Physiol., 1885, 519: 'Untersuchungen über den Stoffwechsel isolirter Organe. I Ein Respirationsapparat für isolirte Organe.'

M. von Frey, Arch. Anat. Physiol., 1885, 533, II; 'Versuche über den Stoffwechsel des Muskels'.

C. Jacobj, Naunyn-Schmiedeberg's Arch. exp. Path. Pharmak., 1890, 26, 388: 'Apparat zur Durch-

blutung isolirter überlebender Organe.'

T. G. Brodie, J. Physiol. (Lond.), 1903, 29, 226: 'The perfusion of surviving organs.' 


\section{Artificial Respiration, the History of an Idea}

of the nineteenth century, but without success, as an anticoagulant was not discovered until 1916. ${ }^{103}$ In 1929 in Russia perfusion was successfully carried out on dogs and isolated dogs' heads; ${ }^{104}$ however the work remained unknown and Gibbon ${ }^{105}$ worked out his own system from 1937 onwards culminating in the first human use in 1953 for an intra-cardiac operation. ${ }^{106}$

Credit should also be given to others like Björk and Crafoord ${ }^{107}$ who, in 1948, introduced the now widely used rotating disc oxygenator, to Clark and Gollan ${ }^{108}$ who developed the first modern bubble oxygenator and to the technical virtuosity of Lillehei and his colleagues ${ }^{109}$ who in turn successfully used perfusion from reservoirs of oxygenated blood, cross circulation, dog lung oxygenators and finally introduced the disposable plastic bubble oxygenator. ${ }^{110}$

Current investigation in this field is on membranes for oxygen transference which do not require haemodilution nor cause erythrocyte damage, in the hope that extracorporeal respiration for days or weeks will be possible. ${ }^{111}$

\section{MEDICINE}

Thus far the techniques of artificial respiration have entered the fields of physiology, resuscitation and surgery. In 1951 during the great Copenhagen poliomyelitis epidemic and its subsequent European spread the technique of positive pressure ventilation extended to the medical field. Lassen ${ }^{112}$ and Ibsen ${ }^{113}$ employed teams of medical students pumping bags filled with oxygen and nitrous oxide, and later air, to sustain life in patients affected with bulbar paralysis. Soon a plethora of automatic machines became available to replace the students. Two of these ventilators are still in wide use throughout the world (Engström ${ }^{114}$ and Radcliffe ${ }^{115}$ ). The new technique swept Europe and parts of the rest of the world, but the United States of America remained resistant to this advance and persisted in the use of the tank respirators until the

108 J. McLean, Am. J. Physiol., 1916, 41, 250: 'The thromboplastic action of cephalin.'

104 S. Brukhonenko, J. Physiol. Path. Gen., 1929, 27, 12: 'Appareil pour la circulation artificielle du sang des animaux a sang chaud.'

S. Brukhonenko and S. Tchetchuline, J. Physiol. Path. Gen., 1929, 27, 31: 'Expériences avec la tête isolée du chien. I Technique et conditions des expériences.'

S. Brukhonenko, J. Physiol. Path. Gen., 1929, 27, 257: "Circulation artificielle du sang dans l'organisme entier d'un chien avec coeur exclu.'

${ }_{106}$ B. J. Miller, J. H. Gibbon, Jr. and C. Fineberg, Med. Clin. N. Amer., 1953, 37, 1603: 'An improved mechanical heart and lung apparatus.'

${ }_{106}$ J. H. Gibbon, Jr., Minnesota Med., 1954, 37, 171 : 'Application of a mechanical heart and lung apparatus to cardiac surgery.'

107 V. O. Björk, Acta chir. Scand. Suppl., 1948, 137, 1 : 'Brain perfusions in dogs with artificially oxygenated blood.'

${ }_{108}$ F. Gollan, Physiology of Cardiac Surgery, Springfield, Illinois, Thomas, 1959.

100 C. W. Lillehei, R. A. De Wall, R. C. Read, H. E. Warden and R. L. Varco, Dis. Chest., 1956, 29, 1: 'Direct vision intracardiac surgery in man using a simple, disposable artificial oxygenator.'

${ }_{110} \mathrm{~L}$. Rendell-Baker, 'History of Thoracic Anaesthesia', in Thoracic Anaesthesia, ed. by W. W. Mushin, Oxford, Blackwell, 1963, p. 650.

111 P. M. Galletti and G. A. Brecher, 1962, Heart Lung Bypass, New York, Greene \& Stratton, 1962.

P. M. Galletti, 'Advances in Heart-Lung Machines', in Advances in Biomedical Engineering and Medical Physics, ed. S. N. Levine, vol. 2, p. 121, New York, Interscience, 1968.

112 H. C. A. Lassen, Lancet, 1953, 1, 37: 'A preliminary report on the 1952 epidemic of poliomyelitis in Copenhagen with special reference to the treatment of acute respiratory insufficiency.'

118 B. Ibsen, Proc. Roy. Soc. Med., 1954, 47, 72: 'The Anaesthetist's viewpoint on the treatment of respiratory complications in poliomyelitis during the epidemic in Copenhagen 1952.'

114 C-G. Engström, Brit. med. J., 1954, ii, 666: 'Treatment of severe cases of respiratory paralysis by the Engström Universal Respirator.'

116 W. R. Russell, E. Schuster, A. C. Smith and J. M. K. Spalding, Lancet, 1956, i, 539: 'Radcliffe respiration pumps.' 


\section{A. Barrington Baker}

mid-1960s. The use of positive pressure respiration is now firmly established in medicine, and is the raison d'être for the vast majority of intensive care units, now one of the most rapidly expanding areas of medical specialization. However once again their use could have benefited medicine much earlier. Brodie ${ }^{116}$ in a letter to the French physiologist Flourens in 1811 suggested the use of curare with artificial respiration by bellows to treat tetanus. In $1858^{117}$ a patient with tetanus was first treated with curare without artificial respiration and died-no doubt as much due to respiratory paralysis as to tetanic spasm. Brodie also foreshadowed medical treatment when, 'It occurred to me that in an animal under the influence of this or of any other poison that acts in a similar manner, by continuing the artificial respiration for a sufficient length of time after natural respiration had ceased, the brain might recover from the impression, which the poison had produced, and the animal might be restored to life.'118

This advice was applied by Fell ${ }^{86}$ who used this technique in the treatment of patients suffering from opium poisoning. Still however the idea had not been fully accepted because it was not until after the Copenhagen poliomyelitis epidemic that severe drug overdosage was regularly treated by artificial respiration. ${ }^{119}$

\section{CONCLUSION}

Today more and more automatic respirators are appearing, each said to be better than the others and almost all antedated in principle by 150 years. There is however a new field of previously uninvented devices based on the Coanda effect ${ }^{120}$ and the associated field of fluidics. ${ }^{121}$ These are compact devices, with no moving parts, both attributes which are clinically useful. The physiological effects of artificial ventilation itself have been investigated, notably over the last twenty years, ${ }^{122}$ with

116 B. Brodie, Union méd. Paris, 1859, 4, 98 : Letter to P. J. M. Flourens.

117 L. A. Sayre, N.Y.J. Med., 1858, 4, 250: 'Two cases of traumatic tetanus.'

118 B. C. Brodie, Phil. Trans. R. Soc. Lond., 1811, 101, 178: 'Experiments and observations on the different modes in which death is produced by certain vegetable poisons.'

110 C. Clemmesen and E. Nilsson, Clin. Pharmacol. Ther., 1961, 2, 220: 'Therapeutic trends in the treatment of barbiturate poisoning, the Scandinavian method.'

A. B. Baker, Med. J. Aust., 1969, 1, 497: 'Early treatment of the unconscious patient suffering from drug overdose.'

${ }_{100}$ H. Coanda, French Patent 792,754 Procédé et dispositif pour faire dévier une veine de fluide pénétrant dans un autre fluide, 1934.

${ }_{121} \mathrm{H}$. Straub and E. Mosley, 'A respirator without moving parts', in Proceedings, Conference on Engineering in Medicine and Biology, 1964, 6, 83, New York, I.E.E.E.

G. J. Ball and B. G. B. Lucas, 'A simple fluid logic ventilator', in Progress in AnaesthesiologyProceedings of Fourth World Congress of Anaesthesiologists, ed. T. B. Boulton, R. Bryce-Smith, M. K. Sykes, G. B. Gillett and A. L. Revell, Amsterdam, Exerpta Medica, 1970, p. 1064.

S. W. Weitzner and B. J. Urban, (1970) 'Fluid Amplifiers: A new approach to the construction of ventilators', in Progress in Anaesthesiology, op. cit., p. 1068.

122 S. A. Thompson, E. H. Quimby and B. C. Smith, Surg. Gyn. Obstet., 1946, 83, 387: 'The effect of pulmonary resuscitative procedures upon the circulation as demonstrated by the use of radioactive sodium.'

S. A. Thompson, J. thorac. Surg., 1948, 17, 323: 'The effect of pulmonary inflation and deflation upon the circulation.'

A. Cournand, H. L. Motley, L. Werkö, and D. W. Richards, Jr., Am. J. Physiol., 1948, 152, 162 : 'Physiologic studies of the effects of intermittent positive pressure breathing on cardiac output in man.'

J. V. Maloney, Jr., J. O. Elam, S. W. Handford, G. A. Balla, D. W. Eastwood, E. S. Brown and R. H. Ten Pas, J. Amer. med. Assoc., 1953, 152, 212: 'Importance of negative pressure phase in mechanical respirators.' 


\section{Artificial Respiration, the History of an Idea}

recent emphasis given to the details of alterations in the type of ventilation itself. ${ }^{123}$ To this end artificial ventilators have been developed to produce varied parameters, ${ }^{124}$ and very recently one which alters only one variable at a time while controlling all other parameters. ${ }^{125}$

Thus the development of artificial respiration is continuing, as it expands to fill an increasing medical need. Its history has been beset with problems of repudiation, forgetfulness, plagiarism and even misrepresentation, which have all had their effects upon its acceptance and development as a major technique in medicine. It is hoped that the lessons learnt will not be forgotten again.

\section{ACKNOWLEDGEMENTS}

The author wishes to thank Dr. G. Whitteridge and Dr. C. Webster for general encouragement and for reading the preliminary draft, and Dr. H. G. Epstein for help with some translation problems.

122 W. E. Watson, Brit. J. Anaes., 1962, 34, 153: 'Some observations on dynamic lung compliance during intermittent positive pressure respiration'. Ibid., p. 502, 'Observations on physiological dead-space during intermittent positive pressure respiration'. Ibid., p. 690, 'Observations on the dynamic lung compliance of patients with respiratory weakness receiving intermittent positive pressure respiration.'

N. A. Bergman, J. Appl. Physiol., 1963, 18, 1049: 'Effect of different pressure breathing patterns on alveolar-arterial gradients in dogs.'

N. A. Bergman, Anesthesiology, 1967, 28, 390: 'Effects of varying respiratory waveforms on gas exchange.'

124 J. Clutton-Brock, Brit. J. Anaes., 1957, 29, 517: 'A variable pattern respirator with phased sampling device.'

W. E. Watson, J. M. K. Spalding and A. C. Smith, Brit. J. Anaes., 1962, 34, 149. 'A respiration pump to provide a variable waveform.'

A. P. Adams, Ph.D. Thesis, London University, 1970: 'The effects of mechanical ventilation on gas transfer within the lung.'

${ }_{185}$ A. Murray Wilson and A. B. Baker, Brit. J. Anaesth., 1971. 'A variable waveform ventilator.' (In preparation.) 